\title{
Simple synthesis and biological evaluation of flocoumafen and its structural isomers
}

\author{
JAE-CHUL JUNG ${ }^{1}$, SOYONG JANG ${ }^{1}$, SEIKWAN OH ${ }^{1}$ and OEE-SOOK PARK ${ }^{2, *}$ \\ ${ }^{1}$ Department of Neuroscience, Ewha Global Challenge, BK21 and Medical Research Institute, \\ School of Medicine, Ewha Womans University, Seoul 158-710, South Korea \\ ${ }^{2}$ Department of Chemistry, Institute for Basic Sciences, College of Natural Sciences, \\ Chungbuk National University, Cheongju 361-763, Chungbuk, Korea \\ e-mail: ospark@cbnu.ac.kr; jcjung10@yahoo.co.kr
}

MS received 13 January 2010; revised 22 March 2010; accepted 22 June 2010

\begin{abstract}
Simple synthesis and biological properties of flocoumafen $\mathbf{1}$ and its structural isomers are described. The key synthetic strategies involve Knoevenagel condensation, Grignard reaction, intramolecular ring cyclization and coupling reaction. Flocoumafen 1 was easily separated into cis and trans forms using flash column chromatography. They were then evaluated for suppression of LPS-induced NO generation and anti-excitotoxicity in vitro. It was found that the trans-flocoumafen was potent suppressor of NO generation with the concentration of $10 \mu \mathrm{M}$ in vitro, while no significant effect for neurotoxicity in cultured cortical neurons.
\end{abstract}

Keywords. Flocoumafen; intramolecular ring cyclization; coupling reaction, NO-generation; neurotoxicity.

\section{Introduction}

Many 4-hydroxycoumarins have been naturally obtained from several plants such as tonka bean, lavender, sweet clover grass, strawberries, and cinnamon. The 4-hydroxycoumarin and its derivatives have been effectively used as anticoagulants such as warfarin, brodifacoum, difethialone, bromadiolone, coumatetralone, and flocoumafen for the treatment of disorders in which there is excessive or undesirable clotting, such as thrombophlebitis, pulmonary embolism, and certain cardiac conditions. ${ }^{1}$ Recently, the 4-hydroxycoumarins have evoked a great deal of interest due to their characteristic structural features and biological activities. The coumarin have been studied as cell growth stimulation, bacteriostatic activity as well as various pharmacological effectiveness such as analgesic, ${ }^{2}$ arthritis, ${ }^{3}$ anti-inflammatory, ${ }^{4}$ anti-pyretic, ${ }^{5}$ anti-bacterial, ${ }^{6}$ anti-viral, ${ }^{7}$ and anticancer effects. ${ }^{8}$ Especially, the flocoumafen 1 and thioflocoumafen $\mathbf{2}$ are very effective anticoagulant agents among the 4-hydroxycoumarin derivatives." The coumarin nucleus is derived from cinnamic acid as phenylacrylic skeleton in the biosynthesis. Espe-

\footnotetext{
*For correspondence
}

cially, the hydroxy group attached to coumarin nucleus at 4-position is important in biosynthesis pathway. Currently, 4-hydroxycoumarins are registered for the control of rats and mice in and around farm structures, households, and domestic dwellings, inside transport vehicles, commercial transportation facilities, and industrial areas. Recent report ${ }^{10}$ described a simple synthesis of 4-hydroxycoumarin derivatives and their screening assay for their biological properties. Actually, most of the work to date, regarding the synthetic approaches of warfarin type anticoagulants were reported ${ }^{11}$ by the Ferreira group through the formation of the carbon backbone using organocopper methodology, the ring cyclization, and the coupling reaction with the 4-hydroxycoumarin moiety.

The scheme 1 reveals representative retrosynthetic approach for syntheses of $\mathbf{1}$ and $\mathbf{2}$. The major synthetic strategies involve intramolecular ring cyclization, $O$-alkylation for preparation of key fragments tetrahydronaphthalen-1-ol $\mathbf{3}$ or tetrahydronaphthalen-1-bromide 4 and coupling reaction of 3, 4 with 4-hydroxycoumarin $\mathbf{5}$ or 4-hydroxythiocoumarin $\mathbf{6}$ to generate the target flocoumafen $\mathbf{1}$ or thioflocoumafen 2. The skeletons of $2 \mathrm{H}-1$ benzopyran-2-ones and tetrahydronaphthalens are 


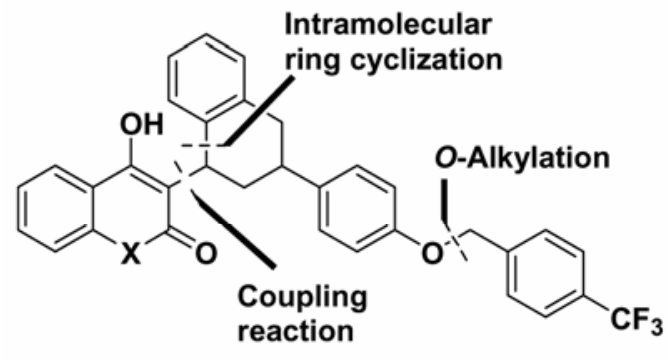

$1 \mathrm{X}=0$, Flocoumafen

$2 \mathrm{X}=\mathrm{S}$, Thioflocoumafen

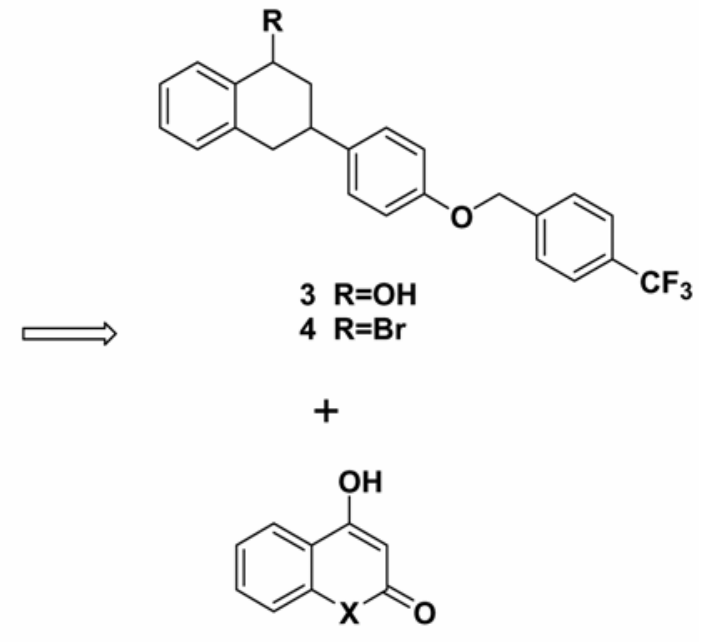

$5 \mathrm{X}=\mathrm{O}, 4$-Hydroxycoumarin

$6 \mathrm{X}=\mathrm{S}, 4$-Hydroxythiocoumarin

Scheme 1. Retrosynthetic analysis of flocoumafen $\mathbf{1}$ and thioflocoumafen 2 .

essential structural features for the 4-hydroxycoumarin derivatives of second generation rodenticides 1-2. They have traditionally been coupled with acidic media. Even though improved condensation reactions of 4-hydroxycoumarins 5-6 with compounds 3 or 4 using Bronsted-Lowry acids $(\mathrm{HCl}$, $\mathrm{H}_{2} \mathrm{SO}_{4}$ ) have been reported, ${ }^{11-12}$ these reactions led to preferential dehyrdohalogenation to give low yield. Thus, an efficient coupling condition was required to obtain high yield.

In the context of our medicinal research program dealing with the synthesis of biologically active 4hydroxycoumarin derivatives, we hope to report a simple synthesis of flocoumafen from intramolecular ring cyclization, $O$-alkylation, and coupling reaction. Flocoumafen 1 was firstly separated into cis form and trans form using flash silica-column chromatography. Biological activities of flocoumafen and its structural isomers for suppression of LPS-induced NO generation in vitro suggests that they can be possible lead compounds for antiinflammatory agents.

\section{Experimental}

\subsection{General}

Reactions requiring anhydrous conditions were performed with the usual precautions for rigorous exclusion of air and moisture. Tetrahydrofuran was distilled from sodium benzophenone ketyl prior to use. Thin layer chromatography (TLC) was performed on precoated silica gel G and GP uniplates from Analtech and visualized with $254 \mathrm{~nm}$ UV light. Flash chromatography was carried out on silica gel 60 [Scientific Adsorbents Incorporated (SAI), particle size $32-63 \mu \mathrm{m}$, pore size $60 \AA]$. ${ }^{1} \mathrm{H}$ NMR and ${ }^{13} \mathrm{C}$ NMR spectra were recorded on a Bruker DPX 500 at $500 \mathrm{MHz}$ and $125 \mathrm{MHz}$, respectively. The chemical shifts are reported in parts per million ( $\mathrm{ppm})$ downfield from tetramethylsilane, and $J$ values are in Hz. Infrared (IR) spectra were obtained on an ATI Mattson FT/IR spectrometer. Mass spectra were recorded with a Waters Micromass ZQ LCMass system and high resolution mass spectra (HRMS) were measured with a Bruker BioApex FTMS system by direct injection using an electrospray interface (ESI). When necessary, chemicals were purified according to the reported procedures. ${ }^{13}$

2.1a Synthesis of 3-[1,2,3,4-Tetrahydro-3-[4-(4trifluoromethylbenzyloxy) phenyl]-1-naphthalen-1-ol (3): To a stirred solution of ketone $(13,0.8 \mathrm{~g}$, $2.0 \mathrm{mmol})$ in $\mathrm{EtOH}(6 \mathrm{~mL})$ was added portion-wise sodium borohydride (91 mg, $2.4 \mathrm{mmol})$ and then the mixture was stirred at room temperature for $2 \mathrm{~h}$. The reaction mixture was diluted with water $(5 \mathrm{~mL})$ and acidified with $1 \mathrm{~N} \mathrm{HCl}$ aqueous solution. The resulting mixture was extracted with dichloromethane $(10 \mathrm{~mL} \times 3)$. The combined organic layer was washed with saturated aqueous $\mathrm{NH}_{4} \mathrm{Cl}$ solution $(15 \mathrm{~mL})$ and organic phase was separated, dried over anhydrous 
$\mathrm{MgSO}_{4}$, filtered, and concentrated under reduced pressure. The residue was purified by flash column chromatography (silica gel, ethyl acetate/hexanes = $1: 3, v / v)$ to afford alcohol $3(0.56 \mathrm{~g}, 70 \%)$ as a white solid. $R_{f}=0.3$ (30\% ethyl acetate/hexanes); m.p. $111.6^{\circ} \mathrm{C}$. IR (neat, $\left.\mathrm{NaCl}\right) \vee 3388(\mathrm{OH}), 2922$ $(\mathrm{C}-\mathrm{H}), 1611(\mathrm{C}=\mathrm{C}), 1584,1512,1454,1244,1066$ $(\mathrm{C}-\mathrm{O}), 824 \mathrm{~cm}^{-1} .{ }^{1} \mathrm{H}$ NMR $\left(\mathrm{CDCl}_{3}, 500.14 \mathrm{MHz}\right) \delta$ $7.63(d d, 3 \mathrm{H}, J=8.5,8.5 \mathrm{~Hz}$, aromatic-H), $7.56(d$, $2 \mathrm{H}, J=8.0 \mathrm{~Hz}$, aromatic-H), 7.29-7.20 $(m, 4 \mathrm{H}$, aromatic-H), $7.10(d, 1 \mathrm{H}, J=7.5 \mathrm{~Hz}$, aromatic-H), 6.95 $(d, 2 \mathrm{H}, J=8.0 \mathrm{~Hz}$, aromatic- $\mathrm{H}), 5 \cdot 13(s, 2 \mathrm{H}$, benzyl$\mathrm{H}), 5.02-4.96(m, 1 \mathrm{H}, \mathrm{CH}), 3.09-2.88\left(m, 2 \mathrm{H}, \mathrm{CH}_{2}\right)$, $2.51-2.45(m, 1 \mathrm{H}, \mathrm{CH}), 1.92(q, 1 \mathrm{H}, J=12.5 \mathrm{~Hz}$, $\left.\mathrm{CH}_{2}\right), 1.78\left(d, 1 \mathrm{H}, J=8.0 \mathrm{~Hz}, \mathrm{CH}_{2}\right) .{ }^{13} \mathrm{C} \mathrm{NMR}$ $\left(\mathrm{CDCl}_{3}, 125.76 \mathrm{MHz}\right) \delta 157.2,141.4,139.3,138.4$, $136 \cdot 4,128 \cdot 7,127.9$ (2C), 127.6, 127.5 (2C), 126.9, $126 \cdot 7,125 \cdot 7$ (2C), $125 \cdot 6(2 \mathrm{C}), 115 \cdot 1$ (2C), 70.3, 69.4, 41.0, 38.7, 38.6. HRMS: $m / z=399 \cdot 1585$ (calcd. 399.1572 for $\mathrm{C}_{24} \mathrm{H}_{22} \mathrm{~F}_{3} \mathrm{O}_{2}:[\mathrm{M}+\mathrm{H}]^{+}$).

2.1b Synthesis of flocoumafen; 4-hydroxy-3-[1,2,3,4tetrahydro-3-[4-(4-trifluoromethylbenzyloxy)phenyl]1-naphthyllcoumarin (1): To a stirred solution of secondary alcohol $(3,0.2 \mathrm{~g}, 0.5 \mathrm{mmol})$ in dichloromethane $(4 \mathrm{~mL})$ was added $p$-toluenesulfonic acid $(5 \mathrm{mg}$, cat) and 4-hydroxycoumarin $(0.1 \mathrm{~g}, 0.6 \mathrm{mmol})$ and then the mixture was refluxed for $6 \mathrm{~h}$. The reaction mixture was cooled to room temperature and washed with water $(5 \mathrm{~mL})$. The organic layer was separated and the aqueous layer was extracted with dichloromethane $(10 \mathrm{~mL} \times 3)$. The combined organic layer was washed with saturated aqueous $\mathrm{NH}_{4} \mathrm{Cl}$ solution $(15 \mathrm{~mL})$ and organic phase was separated, dried over anhydrous $\mathrm{MgSO}_{4}$, filtered, and concentrated under reduced pressure. The residue was purified by flash column chromatography (silica gel, ethyl acetate/hexanes $=1: 4, v / v)$ to give flocoumafen $1(0.18 \mathrm{~g}, 64 \%)$ as a white solid. $R_{f}=0.2$ ( $25 \%$ ethyl acetate/hexanes); m.p. $137 \cdot 5^{\circ} \mathrm{C}$. IR (neat, $\mathrm{NaCl})$ v $3396(\mathrm{OH}), 1668(\mathrm{C}=\mathrm{O}), 1610(\mathrm{C}=\mathrm{C})$, $1570,1510,1452,1419,1326,1240,1066(\mathrm{C}-\mathrm{O})$, $825 \mathrm{~cm}^{-1} .{ }^{1} \mathrm{H}$ NMR $\left(\mathrm{CDCl}_{3}, 500 \cdot 14 \mathrm{MHz}\right) \delta 7.72(d$, $1 / 2 \mathrm{H}, J=8.0 \mathrm{~Hz}$, aromatic-H), 7.68-7.61 $(\mathrm{m}, 5 / 2 \mathrm{H}$, aromatic-H), 7.57-7.50 ( $m, 3 \mathrm{H}$, aromatic- $\mathrm{H}), 7.38$ $7.29(\mathrm{~m}, 4 \mathrm{H}$, aromatic- $\mathrm{H}), 7.28-7.23(\mathrm{~m}, 2 \mathrm{H}$, aromatic-H), $7.19(d d, 2 \mathrm{H}, J=8.5,8.5 \mathrm{~Hz}$, aromatic$\mathrm{H}), 6.91(d d, 2 \mathrm{H}, J=8.5,8.5 \mathrm{~Hz}$, aromatic-H), 5.12 $(s, 1 \mathrm{H}$, benzyl-H), $5 \cdot 10(s, 1 \mathrm{H}$, benzyl-H), $4.86(q$, $1 / 2 \mathrm{H}, J=6.0 \mathrm{~Hz}, \mathrm{CH}), 4.72(t, 1 / 2 \mathrm{H}, J=4.5 \mathrm{~Hz}$, $\mathrm{CH}), 3.23\left(d, 1 / 2 \mathrm{H}, J=12.5 \mathrm{~Hz}, \mathrm{CH}_{2}\right), 3 \cdot 13-2.98$ (m, 5/2H, $\left.\mathrm{CH}, \mathrm{CH}_{2}\right), 2.51-2.40\left(m, 1 / 2 \mathrm{H}, \mathrm{CH}_{2}\right)$, $2.38-2.24\left(m, 1 / 2 \mathrm{H}, \mathrm{CH}_{2}\right), 1.96-1.82(m, 1 / 2 \mathrm{H}$, $\left.\mathrm{CH}_{2}\right) .{ }^{13} \mathrm{C}$ NMR $\left(\mathrm{CDCl}_{3}, 125.76 \mathrm{MHz}\right) \delta 163.5$ $(\mathrm{C}=0), 160.8(\mathrm{C}), 157.2(\mathrm{C}), 157.1$ (C), 152.7 (C), 152.6 (C), 141.3 (C), 138.1 (C), 137.9 (C), 137.7 (C), 134.3 (C), 132.1 (CH), 132.0 (CH), 130.8 (C), $130.7(\mathrm{C}), 130.6(\mathrm{CH}), 129.3(\mathrm{CH}), 128.7(\mathrm{CH})$, $128.1(\mathrm{CH}), 128.0(\mathrm{C}), 127.9(\mathrm{C}), 127.8(\mathrm{C}), 127.5$ (C), $127.4(\mathrm{C}), 125.7$ (C), 125.6 (C), 124.1 (CH), $124.0(\mathrm{CH}), 123 \cdot 2(\mathrm{CH}), 123 \cdot 1(\mathrm{CH}), 116.6(\mathrm{CH})$, $116.5(\mathrm{CH}), 116.3$ (C), $115 \cdot 1$ (C), $115 \cdot 0$ (C), $109 \cdot 4$ (C), 108.8 (C), 69.3 (benzyl-C), 39.8 (CH), 38.6 $\left(\mathrm{CH}_{2}\right), 38 \cdot 1 \quad\left(\mathrm{CH}_{2}\right), 37.5(\mathrm{CH}), 37.0(\mathrm{CH}), 36.5$ $\left(\mathrm{CH}_{2}\right), 35.9\left(\mathrm{CH}_{2}\right)$. HRMS: $m / z=543.1772$ (calcd. 543.1783 for $\mathrm{C}_{33} \mathrm{H}_{26} \mathrm{~F}_{3} \mathrm{O}_{4}$ : $[\mathrm{M}+\mathrm{H}]^{+}$); cis-Flocoumafen: m.p. $180 \cdot 1{ }^{\circ} \mathrm{C} .{ }^{1} \mathrm{H} \mathrm{NMR}\left(\mathrm{CDCl}_{3}, 500 \cdot 14 \mathrm{MHz}\right) \delta$ $7.72(d, 1 \mathrm{H}, J=7.5 \mathrm{~Hz}$, aromatic-H), $7.62(d, 2 \mathrm{H}$, $J=8.0 \mathrm{~Hz}$, aromatic-H), $7.53(d d, 3 \mathrm{H}, J=7.5$, $2.0 \mathrm{~Hz}$, aromatic- $\mathrm{H}), 7.34(d, 1 \mathrm{H}, J=8.0 \mathrm{~Hz}$, aromatic- $\mathrm{H}), 7.32-7.23(\mathrm{~m}, 5 \mathrm{H}$, aromatic- $\mathrm{H}), 7.21(d$, $2 \mathrm{H}, J=9.0 \mathrm{~Hz}$, aromatic-H), $6.92(d, 2 \mathrm{H}, J=9.0$, $8.5 \mathrm{~Hz}$, aromatic-H), $5.64($ brs $, 1 \mathrm{H}, \mathrm{OH}), 5.12(s$, $2 \mathrm{H}$, benzyl-H), $4.87(q, 1 \mathrm{H}, J=5.5 \mathrm{~Hz}, \mathrm{CH}), 3 \cdot 13-$ $3.02\left(m, 3 \mathrm{H}, \mathrm{CH}, \mathrm{CH}_{2}\right), 2.52-2.42\left(m, 1 \mathrm{H}, \mathrm{CH}_{2}\right)$, $1.95-1.80\left(m, 1 \mathrm{H}, \mathrm{CH}_{2}\right)$; LC-MS $\left(\mathrm{ESI}^{+}\right) \mathrm{m} / z$ 565.1 $[\mathrm{M}+\mathrm{Na}]$; trans-Flocoumafen: m.p. $107 \cdot 3^{\circ} \mathrm{C} .{ }^{1} \mathrm{H}$ NMR $\left(\mathrm{CDCl}_{3}, 500.14 \mathrm{MHz}\right): \delta=7.66(d d, 1 \mathrm{H}$, $J=1.5,1.5 \mathrm{~Hz}$, aromatic-H), $7.63(d, 2 \mathrm{H}, J=8.0 \mathrm{~Hz}$, aromatic- $\mathrm{H}), 7.57-7.52(\mathrm{~m}, 3 \mathrm{H}$, aromatic- $\mathrm{H}), 7.39-$ $7.34(m, 2 \mathrm{H}$, aromatic- $\mathrm{H}), 7.33-7.29(m, 2 \mathrm{H}$, aromatic- $\mathrm{H}), 7 \cdot 27-7.20(\mathrm{~m}, 2 \mathrm{H}$, aromatic- $\mathrm{H}), 7 \cdot 16$ $(d, 2 \mathrm{H}, J=8.5 \mathrm{~Hz}$, aromatic-H), $6.90(d, 2 \mathrm{H}$, $J=8.5 \mathrm{~Hz}$, aromatic-H), $5.12(s, 2 \mathrm{H}$, benzyl-H), $4.72(t, 1 \mathrm{H}, J=4.0 \mathrm{~Hz}, \mathrm{CH}), 3.23(d, 1 \mathrm{H}, J=$ $\left.12.0 \mathrm{~Hz}, \mathrm{CH}_{2}\right), 3 \cdot 12-2.99\left(\mathrm{~m}, 2 \mathrm{H}, \mathrm{CH}, \mathrm{CH}_{2}\right), 2 \cdot 36-$ $2.32\left(\mathrm{~m}, 2 \mathrm{H}, \mathrm{CH}_{2}\right)$; LC-MS $\left(\mathrm{ESI}^{+}\right) \mathrm{m} / \mathrm{z} 565.3-$ $[\mathrm{M}+\mathrm{Na}]$.

\subsection{Biological activity test}

2.2a Cell culture: Cerebral cortices were removed from the brains of 15.5-day-old fetal mice. The neocortices were triturated and plated on 24-well plates (with approximately $10^{6}$ cells $/ \mathrm{mL}$ ) precoated with $100 \mu \mathrm{g} / \mathrm{mL}$ poly-D-lysine and $4 \mu \mathrm{g} / \mathrm{mL}$ laminine, in Eagle's minimal essential media (Earle's salts, supplied glutamine-free), and supplemented with horse serum (5\%), fetal bovine serum (5\%), $2 \mathrm{mM}$ glutamine, and $20 \mathrm{mM}$ glucose. Cultures were maintained at $37^{\circ} \mathrm{C}$ in a humidified atmosphere of $5 \% \mathrm{CO}_{2}$. After 6 days in vitro (DIV), the cultures were shifted 
to the plating media containing $10 \mu \mathrm{M}$ cytosine arabinoside without fetal serum. Cultures were then fed twice per week. Mixed cortical cell cultures containing neurons and glia (DIV 16-14) were exposed to excitatory amino acid, glutamate, in Eagle's minimal essential media without serum. The morphology of the degenerating neurons was observed under a phase contrast microscope over the next $24 \mathrm{~h}$. The murine BV2 cell line (a generous gift from Dr. W. Kim, Korea Research Institute of Bioscience and Biotechnology, Korea), which is immortalized after infection with a v-raf/v-myc recombinant retrovirus, exhibits the phenotypic and functional properties of reactive microglial cells ${ }^{14} \mathrm{BV} 2$ cells were maintained at $37^{\circ} \mathrm{C}$ at $5 \% \mathrm{CO}_{2}$ in DMEM supplemented with $10 \% \mathrm{FBS}, 100 \mu \mathrm{g} / \mathrm{mL}$ streptomycin, and $100 \mathrm{U} / \mathrm{mL}$ penicillin. BV2 cells were grown in 24 -well plates at a concentration of $1 \times 10^{5}$ cells/ well followed by proper treatment.

$2.2 \mathrm{~b}$ Nitrite assay: NO production from activated microglial cells was determined by measuring the amount of nitrite, a relatively stable oxidation product of NO, as described previously. ${ }^{15}$ Cells were incubated with or without LPS $(1 \mu \mathrm{g} / \mathrm{mL})$ in the presence or absence of various concentrations of compounds for $24 \mathrm{~h}$. The nitrite accumulation in the supernatant was assessed by Griess reaction. In brief, an aliquot of the conditioned medium was mixed with an equal volume of $1 \%$ sulfanilamide in water and $0 \cdot 1 \% \mathrm{~N}-1$ naphthylethylenediamine dihydrochloride in $5 \%$ phosphoric acid. The absorbance was determined at $540 \mathrm{~nm}$ in an automated microplate reader.

2.2c Cell viability: Cortical neuronal cell number and viability were assessed by using the reagent WST-1 (Roche, Indianapolis, IN). This colorimetric assay measures the metabolic activity of viable cells based on cleavage of the tetrazolium salt WST-1 substrate 4-[3-(4-iodophenyl)-2-(4-nitrophenyl)-2H5-tetrazolio-1,3-benzene disulphonate into formazan by mitochondrial dehydrogenase in live cells. This was followed by incubation with WST-1 reagent at a dilution of $1: 10$ in the original conditioned media at $37^{\circ} \mathrm{C}$ for $2 \mathrm{~h}$. After thorough shaking, the formazan produced by the metabolically active cells in each sample was measured at a wavelength of $450 \mathrm{~nm}$ and a reference wavelength $650 \mathrm{~nm}$. Absorbance readings were normalized against control wells with untreated cells. Neuronal death was analysed $24 \mathrm{~h}$ later, and the percentage of neurons undergoing actual neuronal death was normalized to the mean value that is found after a $24 \mathrm{~h}$ exposure to $300 \mu \mathrm{M}$ NMDA (defined as 0 ) or a sham control (defined as 100).

\section{Results and discussion}

\subsection{Chemistry}

The linear synthesis of flocoumafen $\mathbf{1}$ is summarized in scheme 2. Commercially available 4-methoxybezaldehyde 7 was condensed with dimethyl malonate as a Knoevenagel condensation in the presence of $\mathrm{AcOH}$ and pyrrolidine to afford diketo ester 8, which was treated with freshly prepared benzylmagnesium bromide in the presence of copper (I) chloride to give compound 9 . Subsequent hydrolysis of 9 was accomplished with aqueous potassium hydroxide. The resulting diacid $\mathbf{1 0}$ was decarboxylated under acidic condition and then cyclized intramolecularly using polyphosphoric acid to yield tetralone $\mathbf{1 1}$ in two steps. ${ }^{16}$ Demethylation of tetralone 11 was performed by hydrobromic acid in acetic acid to give phenol 12. It was $O$-alkylated with freshly prepared 3-(trifluoromethyl)benzyl bromide in sodium hydride/ THF to generate ether $13{ }^{17}$ Reduction of ketone group of compound 13 with sodium borohydride in methanol gave secondary alcohol 3, which was treated with $p$-toluenesulfonic acid to give flocoumafen $1^{18}$ in $64 \%$ yield as $1: 1$ structural isomeric mixture.

On the other hand, the coupling reaction of bromide 4 with 4-hydroxycoumarin 5 was not effective for preparation of flocoumafen 1 due to generation of undesired dehydroxyhalogenated product and almost recovered starting materials. The obtained flocoumarin 1 was a $1: 1$ mixture of $c i s$-flocoumafen (cis-FCF) and trans-flocoumafen (trans-FCF). For the biological activity test, we separated it into cisFCF and trans-FCF using flash silica-column chromatography. Also, we could recrystallize flocoumarin 1 using the co-solvent (ethyl acetate/hexanes) system in order to separately yield cis and trans forms.

\subsection{Suppression of NO-generation and anti- neurotoxicity}

NO production from activated microglial cells was determined by measuring the amount of nitrite after incubation with or without LPS $(1 \mu \mathrm{g} / \mathrm{mL})$ in the presence or absence of various concentrations of 
<smiles>COC(=O)C(=Cc1ccc(OC)cc1)C(=O)OC</smiles><smiles>[R]c1ccc(C2CC(=O)c3ccccc3C2)cc1</smiles><smiles>CC(C)(C)C(F)(F)c1ccc(COc2ccc(C3Cc4ccccc4C(O)C3)cc2)cc1</smiles>

Scheme 2. Reagents and conditions: (a) Dimethyl malonate, AcOH, pyrrolidine, toluene, reflux, $3 \mathrm{~h}$; (b) benzylmagnesium bromide, $\mathrm{Cu}_{2} \mathrm{Cl}_{2}, \mathrm{THF}, 0^{\circ} \mathrm{C}$, $1 \mathrm{~h}$; (c) $\mathrm{KOH} / \mathrm{H}_{2} \mathrm{O}$, reflux, $3 \mathrm{~h}$; (d) $\mathrm{H}_{2} \mathrm{SO}_{4} / \mathrm{H}_{2} \mathrm{O}$, reflux, $8 \mathrm{~h}$; and then PPA, $80^{\circ} \mathrm{C}$, $1 \mathrm{~h}$; (e) $\mathrm{HBr}, \mathrm{AcOH}$, reflux, $6 \mathrm{~h}$; (f) 3 -(trifluoromethyl)benzyl bromide, sodium hydride, THF, $0^{\circ} \mathrm{C}, 1 \mathrm{~h}$; (g) $\mathrm{NaBH}_{4}, \mathrm{MeOH}$, r.t., 2 h; (h) 4-hydroxycoumarin, $p$ $\mathrm{TsOH}$, dichloromethane, $80^{\circ} \mathrm{C}, 3 \mathrm{~h}$.

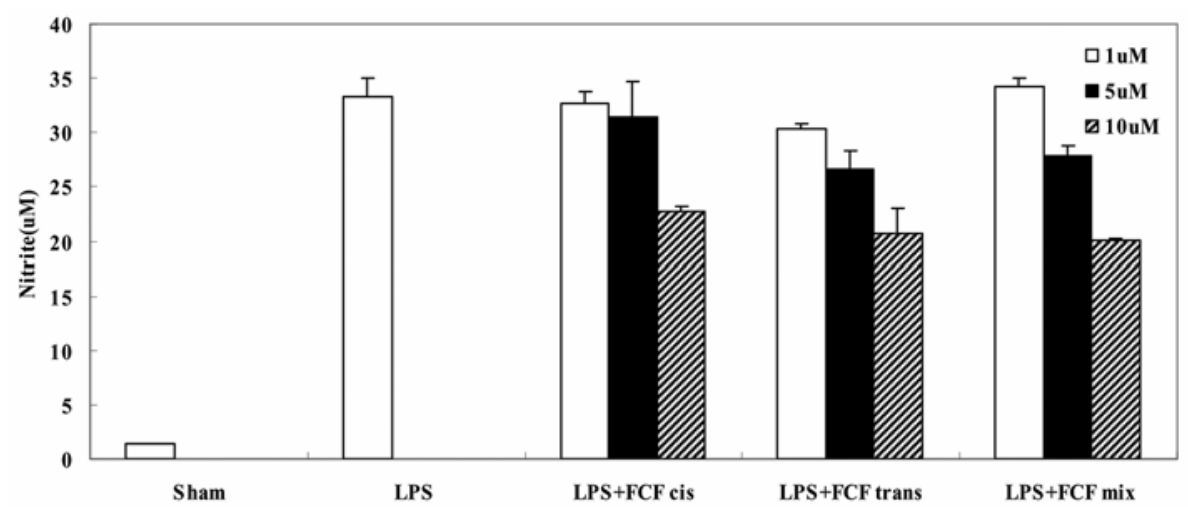

Figure 1. Suppression of NO production in LPS-treated microglia. The cells were treated with $1 \mu \mathrm{g} / \mathrm{mL}$ of LPS only or LPS plus different concentrations (1, 5 , and $10 \mu \mathrm{M})$ of compounds at $37^{\circ} \mathrm{C}$ for $24 \mathrm{~h}$. At the end of incubation, $50 \mu \mathrm{L}$ of the medium was removed to measure nitrite production. All values represent mean \pm SE of three independent experiments performed in triplicate.

compounds for $24 \mathrm{~h}$. All compounds $(10 \mu \mathrm{M})$ showed considerable suppression of LPS-induced NO generation (figure 1). The trans form of FCF has more potent activity than that of cis-FCF in antiinflammatory action. However, cis-FCF is slightly more active than trans-FCF in the inhibition of glutamate-induced neurotoxicity in cultured cortical neurons. Exposure of cortical cell cultures to $300 \mu \mathrm{M}$ NMDA (prototype of glutamate receptor agonist) resulted in a rapid swelling of the neuronal cell body within $2 \mathrm{~h}$, and caused 90 to $100 \%$ neuronal death over the next day. The $60 \mu \mathrm{M}$ of glutamate induced the $60 \%$ of neurotoxicity after $24 \mathrm{~h}$ exposure in cultured neurons. These excitotoxic neuronal deaths were weakly prevented by all of compounds $(1 \mu \mathrm{M})$ (figure 2$)$. The results revealed that suppression of NO production in LPS-treated microglia cell of the trans-flocoumafen is increased 


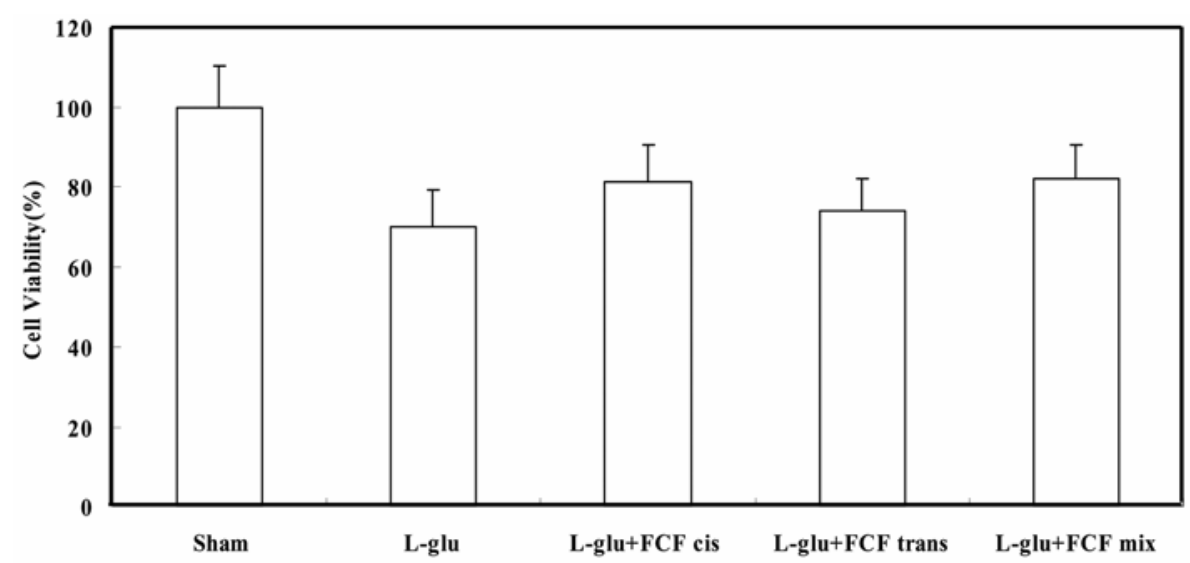

Figure 2. Inhibition of glutamate-induced neurotoxicity in cultured cortical neurons. Glutamate $(60 \mu \mathrm{M})$ and compounds $(1 \mu \mathrm{M})$ were applied for $24 \mathrm{~h}$ at $37^{\circ} \mathrm{C}$. After incubation of neurons with water soluble tetrazolium salts WST-1 for $2 \mathrm{~h}$, the compounds were quantified spectrophotometrically. All values represent the mean \pm S.E. of three independent experiments performed in triplicate.

much more than that of the cis-flocoumafen due to the favourable electronic conjugation system. We have found that the trans-FCF exhibited significantly high efficacy comparable to mix-FCF or cisFCF in vitro LPS-induced NO generation, while all of them did not show significant neurotoxicity in cultured cortical neurons.

\section{Conclusion}

We synthesized flocoumafen 1 from inexpensive and readily available materials and then separated it into cis-flocoumafen (cis-FCF) and trans-flocoumafen (trans-FCF). Their biological activities have been evaluated for the NO generation and antiexcitotoxicity in vitro. We expect that this simple synthesis of flocoumafen 1 and key fragments are useful for the synthesis of flocoumafen analogues.

\section{Acknowledgements}

This work was supported by the research grant of the Chungbuk National University in 2009.

\section{References}

1. Au N and Rettie A E 2008 Drug Metabolism Rev. 40 355

2. Ghate M, Kusanur R A and Kulkarni M V 2005 Eur. J. Med. Chem. $\mathbf{4 0} 882$

3. Cuzzocrea S, Mazzon E, Bevilaqua C, Costantino G, Britti D, Mazzullo G, De Sarro A and Caputi AP 2000 Brit. J. Pharmacol. 1311399
4. Kontogiorgis C A and Hadjipavlou-Litina D J 2005 J. Med. Chem. 486400

5. Kurokawa M, Kumeda C A, Yamamura J I, Kamiyama T and Shiraki K 1998 Eur. J. Pharmacol. 34845

6. Nawrot-Modranka J, Nawrot E, and Graczyk J, 2006 Eur. J. Med. Chem. 411301

7. Al-Soud Y A, Al-Sa'doni H H, Amajaour H A S, Salih K S M, Mubarak M S, Al-Masoudi N A and Jaber I H 2008 Zeit. Fuer Naturforschung, B. Chem. Sci. 6383

8. Nolan $\mathrm{K}$ A, Zhao $\mathrm{H}$, Faulder $\mathrm{P} F$, Frenkel A D, Timson D J, Siegel D, Ross D, Jr. Burke T R, Stratford I J and Bryce R A 2007 J. Med. Chem. 50 6316

9. Ito Y 2003 Med. Entomol. Zool. 54337

10. Stanchev S, Momekov G, Jensen F and Manolov I 2008 Eur. J. Med. Chem. 43694

11. Van Heerden P S, Bezuidenhoudt B C B and Ferreira D 1997 J. Chem. Soc. Perkin Trans. 181141

12. Chen D U, Kuo P Y and Yang D Y 2005 Bioorg. \& Med. Chem. Lett. 152665

13. Armarego W L F, Perrin D D and ButterworthHeinemann 1997 Purification of Laboratory Chemicals (Oxford: Pergamon Press) 4th edn

14. Bocchini V, Mazzolla R, Barluzzi R, Blasi E, Sick P and Kettenmann H J 1992 J. Neurosci. Res. 31616

15. Green L C, Wagner D A, Glogowski J, Skipper P L, Wishnock J S and Tannenbaum PSR 1982 Anal. Biochem. 126131

16. Selvaraj S, Rajendran A S and Arumugam N 1987 Indian J. Chem. B26 1047

17. Jung J C, Kim J C and Park O S 1999 Synth. Commun. 293587

18. Park O S and Jang B S 1995 Arch. Pharm. Res. 18 277 